\title{
Gendered

\section{Gendered Innovations in Orthopaedic Science: Civil Liberties, Darwin, and the Evolution of Science}

\author{
Amy L. Ladd MD
}

\footnotetext{
T
} $\mathrm{f}$ an international colleague were to ask, I might sum up the history of American civil liberties like this: Slaves, women, and children are people, too. Strike that. Slaves, women, and children are persons, too. Nowadays, courts prefer persons over

\section{Note from the Editor-in-Chief:}

We are pleased to present to readers of Clinical Orthopaedics and Related Research ${ }^{\circledR}$ the latest installment of "Gendered Innovations in Orthopaedic Science" by Amy L. Ladd MD. Dr. Ladd is a Professor in the Department of Orthopaedics at Stanford University, and is the PastPresident of the Ruth Jackson Orthopaedics Society. She provides commentary on sex and gender similarities and differences in orthopaedics.

The author certifies that she, or any members of her immediate family, have no funding or commercial associations (eg, consultancies, stock ownership, equity interest, patent/ licensing arrangements, etc) that might pose a conflict of interest in connection with the submitted article.

All ICMJE Conflict of Interest Forms for authors and Clinical Orthopaedics and Related Research ${ }^{\circledR}$ editors and board members are on file with the publication and can be viewed on request.

The opinions expressed are those of the writers, and do not reflect the opinion or policy of Clinical Orthopaedics and Related Research $^{\circledR}$ or the Association of Bone and Joint Surgeons ${ }^{\mathbb{R}}$. people. And hold on-a recent lawsuit [12] suggests chimps are persons too, as sentient beings who possess rights.

How does this relate to orthopaedic science, or better yet, science in general? As it turns out, how we define people/persons is more legal than physical or metaphysical, in that it is determined by societal norms and collective thought. Our definitions float through the sea of humanity reflecting how we promote and improve musculoskeletal research and healthcare, and the greater body of science. Sadly, society dictates science. Charles Darwin, who struggled with the duality of the natural world before him and the spiritual upbringing so central to his core, also loved language and a pithy saying. On approaching science, he said one "... ought to have no wishes, no affections,- - a mere heart of stone" [7]. Darwin viewed himself and his quest for knowledge, as "... turned into a sort of

\section{A. L. Ladd MD ( $ه)$}

Chase Hand and Upper Limb Center, Stanford University, 770 Welch Rd., Suite 400, Palo Alto, CA 94304-1801, USA

e-mail: alad@stanford.edu machine for observing facts and grinding out conclusions" [8].

Darwin viewed words as windows to both history and origin. This seminal way of thinking is blended with evolutionary doctrine and surmised from keen observations both of insects and the behavior of his (ch)impish children [13]. One of his more famous lines in the Origin of Species [6] upended the scientific world: "Man is descended from a hairy, tailed quadruped, probably arboreal in its habits." This was well displayed in a cartoon of the times (Fig. 1).

Darwin chose his words carefully, and sometimes playfully. The editors of this Journal have highlighted the importance of conscious and conscientious word choices when engaged in scientific reporting $[15,16]$. In the spirit of careful word play and usage, I will share some etymologies that highlight the importance of the words we choose.

\section{People, Man, and Homo sapiens}

\section{People Versus Persons}

Let us first look at the word "people," which originated from the Latin 


\section{Gendered Innovations in Orthopaedic Science}

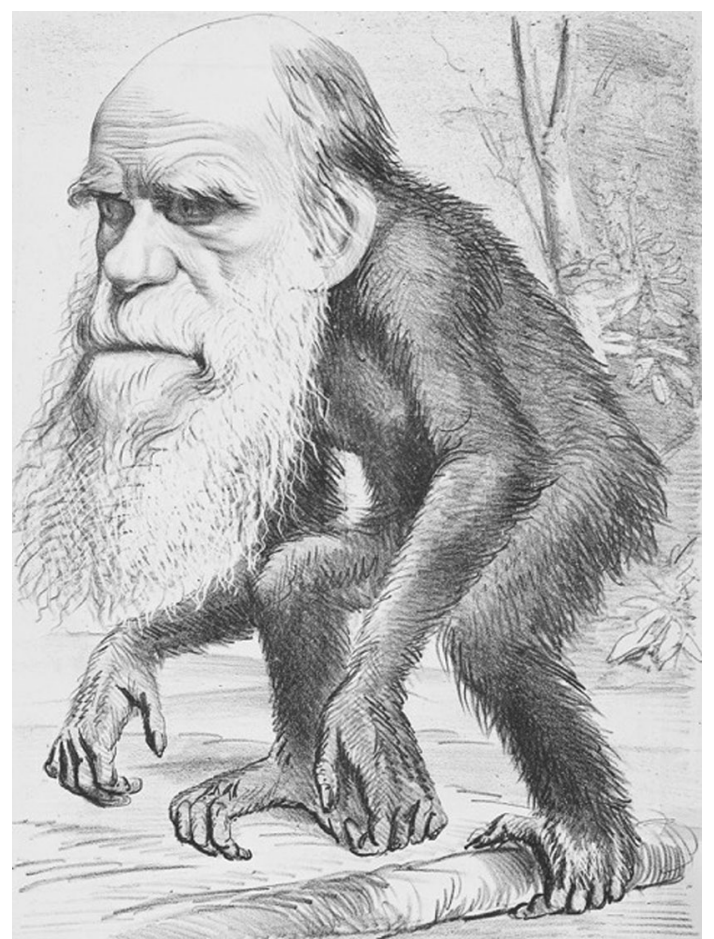

Fig. 1 A caricature of Charles Darwin as an ape published in The Hornet, a satirical magazine, in 1871.

"populous," meaning nation, as in the general public-the populace [21]. Compare "populace" with "person." Derived from the Latin word "persona" for mask or role, the word "person" emphasizes the individual as opposed to a collective body [22]. Perhaps like me, you learned that the plural of person is people, and persons is incorrect-or at least stilted in writing and in speech. But through the evolution of legalese perhaps, persons now describes a collective-whether beings or businesses-who hold individual rights and responsibilities. This is how the Nonhuman Rights Project has come to view a chimpanzee as a person [12].

How about "man" and "mankind?" A revisionist take is that man and men historically embraced women and

\section{Man Versus Mankind}

children. As such, "manhood," "mankind," or "Age of Man," collectively reflect a "we're-all-in-it-together" sort of mentality. Feminists in the 1960s and 1970s protested the male-dominant language slant and we now use neutered words that remove a male or female assumption: "Chair" rather than "chairman" and "flight attendant" rather than "stewardess." Sadly, this era could not find the counterbalance to "feminist"- "masculinist" does not quite roll off the tongue. The word "feminist" for some, has taken on a pejorative meaning, though not as completely as the word "misogynist."

"Man" comes from the Old English "mann" (yes, birthed somewhere near the Isle of Man). Linguists and lexicographers alike debate whether "mann" stands alone as a generic human, or shorthand for a variety of words that include "wæpenmann" [19]. Let there be no doubt, "wœpen" indicates both a battle weapon, and a bit of anatomy unique to the male species. If "mann" ever represented both sexes, then "wyfmann" evolved into modern-day woman with no counterbalance other than woman as an entity completing man. Indeed, when the first edition of the Encyclopedia Britannica was published in 1771 , the entry for "woman" in its entirety, read: “'Female of Man.' See HOMO" [24]. I suggest using "humankind" or "humanity" rather than 


\section{Gendered Innovations in Orthopaedic Science}

"mankind" or "man/men" when speaking of the human race for clarity, simplicity, and, if nothing else, domestic harmony.

\section{Homo sapiens}

Moving on to the big one: Homo sapiens. Having a different route than man, the Latin Genus Homo derives from Proto-Indo-European "dheghom," meaning earthling. Finally-an original, neutral word for men, women, and children! "Sapiens" means to taste, to know, and implies wisdom [10]. Although we are sentient creatures-creatures that are aware and possess the ability to feel-these traits are not uniquely human. Our chimp champions [12], anyone from the Humane Society, or a loving dog greeting you at the door will remind you of that. Instead, Homo sapiens are distinguished from other animals by superior mental development, power of articulate speech, and an upright stance.

\section{Language and the American Civil Liberties}

Armed with human etymologies, let us take a two-legged sprint through the history of American civil liberties that have shaped science and scientific discovery (Table 1). At the start, a feature of enduring laws and acts is the vagueness of legalese, intentionally meant to be fluid and open to interpretation through the decades and centuries. Thus, the preamble, so to speak, through the origin of words and species.

\section{Orthopaedics}

Where does that leave us in the world of orthopaedic science? These legal definitions mirror the conscience of society in recognizing its collective needs and rights. No formal testing requirements for drugs, devices, or other healthcare advances that distinguished women, men, and children existed until legislation of suffrage or undue process heightened awareness across the board. If orthopaedic scientists look carefully into this mirror, we will find discrimination against women, children, and other minorities exist in meaningful, important way$\mathrm{s}$ - even if unintended or overlooked. President Theodore Roosevelt signed into law The Food and Drugs Act in 1906, paving the way for what would eventually become the FDA. Various reforms in the handling of pharmaceuticals and devices unfolded in accordance with social conscience thereafter. As recently as 1977, however, the FDA prohibited women of childbearing age from being involved with the testing of new pharmaceuticals. Although this sought to protect women in the wake of the thalidomide experience in Europe and that of diethylstilbestrol in the United States, the untoward effect of dosages tested only in men have harmed women [9].

The change began just recently in 1993, when the FDA recommended gender-specific analyses that complemented President Clinton's signing the National Institutes of Health Revitalization Act, emphasizing clinical trials specific to women and minorities [20]. Guidelines for children have similarly lagged; extrapolation of adult pharmaceutical dosages has long been the rule. Pediatricians led the charge to change, and recommendations finally culminated with the 2002 Best Pharmaceuticals for Children Act [18]. But even today, women, minorities, and children are underrepresented in clinical trials related to pharmaceuticals and devices at all levels. For instance, the Revitalization Act does not apply to early phase medical studies [9].

If history serves - similar to the history of civil liberties — we tend to dismiss mysterious conditions and ailments. We toss them into a bin of things that do not really exist until defined or discovered through the investigative rubric of scientific progress. Until there were real diagnostic tests like electromyography, carpal tunnel was largely considered a psychosomatic disease of hysteria (from 


\section{Gendered Innovations in Orthopaedic Science}

Table 1. Civil liberties that helped shape scientific discovery in the United States

\begin{tabular}{|c|c|c|c|}
\hline Civil liberties & Year(s) & Key text & Between the lines \\
\hline Magna Carta & 1215 & $\begin{array}{l}\text { "No free man shall be taken, imprisoned, dispossessed, } \\
\text { outlawed, banished, or in any way destroyed, nor will } \\
\text { We proceed against or prosecute him, except by the } \\
\text { lawful judgment of his peers or by the law of the } \\
\text { land." [4]. }\end{array}$ & $\begin{array}{l}\text { Introduced habeus corpus into common law, which } \\
\text { required proof of ownership or right to imprison } \\
\text { another individual. Proof that such individuals } \\
\text { existed meant they possessed certain rights, or lack of } \\
\text { rights. }\end{array}$ \\
\hline $\begin{array}{l}\text { Declaration of } \\
\text { Independence }\end{array}$ & 1776 & $\begin{array}{l}\text { "We hold these truths to be self-evident that all men are } \\
\text { created equal." [3] }\end{array}$ & $\begin{array}{l}\text { Slaves as chattel (property) were part of the original } \\
\text { document, but left out given the moral controversy of } \\
\text { slavery at the time. }\end{array}$ \\
\hline $\begin{array}{l}\text { The US } \\
\text { Constitution and } \\
\text { the Bill of } \\
\text { Rights }\end{array}$ & 1789 & "We the People" [3]. & $\begin{array}{l}\text { "People" represented men of the male sex who held } \\
\text { property; slaves were not specifically mentioned, } \\
\text { although alluded to as "a person held to service or } \\
\text { labor" and trade that included of "importation of } \\
\text { Persons." [26]. Women as entities, individuals, or } \\
\text { persons were not considered or mentioned. }\end{array}$ \\
\hline $\begin{array}{r}\text { Gettysburg } \\
\text { Address }\end{array}$ & 1863 & $\begin{array}{l}\text { "... government of the people, by the people, for the } \\
\text { people shall not perish from the earth." [1]. }\end{array}$ & $\begin{array}{l}\text { Only } 272 \text { words, yet widely regarded as one of the } \\
\text { greatest speeches in American history [1]. }\end{array}$ \\
\hline $15^{\text {th }}$ Amendment & 1870 & $\begin{array}{l}\text { "Rights of citizens of the United States to vote shall not } \\
\text { be denied or abridged by the United States or by any } \\
\text { state on account of race, color, or previous condition } \\
\text { of servitude" [23]. }\end{array}$ & $\begin{array}{l}\text { Part of the postwar Reconstruction legislative sweep. } \\
\text { The } 15^{\text {th }} \text { Amendment provided the broad stroke of } \\
\text { citizenship and voter's rights to individuals based on } \\
\text { adjectives of "race, color, or previous condition of } \\
\text { servitude." Sex was not one of them, however. That } \\
\text { habeus corpus existed for slaves ironically helped } \\
\text { legalize their freedom and voting rights. }\end{array}$ \\
\hline $19^{\text {th }}$ Amendment & 1920 & $\begin{array}{l}\text { "The right of citizens of the United States to vote shall } \\
\text { not be denied or abridged by the United States or by } \\
\text { any State on account of sex." [17]. }\end{array}$ & $\begin{array}{l}\text { Identical to the } 15^{\text {th }} \text { Amendment except specific for sex. } \\
\text { Introduced in } 1878 \text {, but was not ratified until } 1920 \text {. } \\
\text { Unlike language for slaves and former slaves, } \\
\text { language of sex or the existence of women as persons } \\
\text { had not previously been defined in constitutional law. } \\
\text { This contributed to the long delay. }\end{array}$ \\
\hline World War II & $\begin{array}{r}1939- \\
1945\end{array}$ & "Do Your Part" [27] & $\begin{array}{l}\text { A US Employment Service slogan that helped galvanize } \\
\text { women in the workforce [27]. Women were } \\
\text { recognized as political and economic contributors to } \\
\text { American society. }\end{array}$ \\
\hline Civil Rights Act & 1964 & $\begin{array}{l}\text { Made it unlawful for an employer to "fail or refuse to } \\
\text { hire or to discharge any individual, or otherwise to } \\
\text { discriminate against any individual with respect to his } \\
\text { compensation, terms, conditions or privileges or } \\
\text { employment, because of such individual's race, color, } \\
\text { religion, sex, or national origin." [5]. }\end{array}$ & $\begin{array}{l}\text { Unified voter registration requirements. Established the } \\
\text { basis for scrutinizing fairness in education, which led } \\
\text { to forming the Department of Education and the } \\
\text { enactment of Title IX. }\end{array}$ \\
\hline
\end{tabular}




\section{Gendered Innovations in Orthopaedic Science}

Table 1. continued

\begin{tabular}{|c|c|c|c|}
\hline Civil liberties & Year(s) & Key text & Between the lines \\
\hline Title IX & 1972 & $\begin{array}{l}\text { "No person in the United States shall, on the basis of } \\
\text { gender, be excluded from participation in, be denied } \\
\text { the benefits of, or be subjected to discrimination } \\
\text { under any education program or activity receiving } \\
\text { federal financial assistance." [25] }\end{array}$ & $\begin{array}{l}\text { An amendment to the } 1964 \text { Civil Rights Act that } \\
\text { focused on education. Today, most commonly } \\
\text { associated with athletics. The } 37 \text { words of legalese, } \\
\text { however, do not explicitly mention athletics [14]. }\end{array}$ \\
\hline
\end{tabular}

the Greek "hustera" for womb [11])_-in women, naturally. Seronegative arthritis, chronic fatigue syndrome, and many of our diseases that are either sex-mediated or predominant in the male or female sex, may have precise genetic or environmental causes yet to be determined. Growing pains-beyond Osgood-Schlatter-may have real physeal or muscular aberrations or stresses that eventually merit physiologic explanation.

We are familiar with contemporary physicist Stephen Hawking, struck at a young age with amyotrophic lateral sclerosis. Progressive weakness has fueled his passion for living, and his contributions to science, philosophy, and society have far outlived his dim prognosis and anyone's wildest expectations. With one of the defining human characteristics-standing upright-deprived of him, he has seized all that it is to be sentient and knowing, in his incalculable contributions to science and society. Like Darwin before him, he recognized the responsibility we have to continue to ask questions, to open the door to discovery for men, women, and children, and other sentient beings. To quote Hawking: "For millions of years, mankind lived just like the animals. Then something happened which unleashed the power of our imagination. We learned to talk and we learned to listen" [2].

We shall forgive him the use of "mankind."

\section{References}

1. Abraham Lincoln Online. Writings and Speeches. The Gettysburg Address. Available at: http://www. abrahamlincolnonline.org/lincoln/ speeches/gettysburg.htm. Accessed January 26, 2015.

2. Brunner J. Stephen Hawking's wisdom: 17 quotes from the man who inspired 'The Theory of Everything.' Available at: http://parade.com/366671/ jerylbrunner/stephen-hawkings-wisdom-17-quotes-from-the-man-whoinspired-the-theory-of-everything/. January 18, 2015.
3. Constitution of the United States. Available at: http://www.archives. gov/exhibits/charters/constitution_ transcript.html. Accessed January 18, 2015.

4. Constitution Society. The Magna Carta (the great charter). Available at: http://www.constitution.org/eng/magnacar.htm. Accessed January 26, 2015.

5. Civil Rights Act of 1964, Pub.L. 88352, 78 Stat. 241 (1964).

6. Darwin C. On the Origin of Species by Means of Natural Selection, or the Preservation of Favoured Races in the Struggle for Life. 1st ed. London, UK: John Murray; 1859.

7. Darwin Correspondence Project. Letter 2122. Darwin, C. R. to Huxley, T. H. 9 July 1857. Available at: http:// www.darwinproject.ac.uk/letter/entry2122. Accessed January 16, 2015.

8. Darwin Online. The Darwin letters at Shrewsbury school. Available at: http:// darwin-online.org.uk/content/frameset? viewtype=text\&itemID=A538\&page seq=1. Accessed January 17, 2015.

9. Gendered Innovations in Science Health and Medicine, Engineering and Environment. Designing health and biomedical research. Available 


\section{Gendered Innovations in Orthopaedic Science}

at: http://genderedinnovations.stanford.edu/methods/health.html. Accessed January 24, 2015.

10. Homo sapiens. Available at: http:// www.thefreedictionary.com/Homo+ sapiens. Accessed January 28, 2015.

11. Hysteria. Available at: http://dictionary.reference.com/browse/hysteria. Accessed January 28, 2015.

12. Keim B. Case for chimpanzee rights rejected by appeals court. Available: http://www.wired.com/2014/12/courtsays-chimp-not-a-person. Accessed January 16, 2015.

13. Keynes R. Annie's Box: Charles Darwin, His Daughter, and Human Evolution. London, UK: Fourth Estate; 2001.

14. Ladd AL. The sports bra, the ACL, and Title IX - the game in play. Clin Orthop Relat Res. 2014;472:1681-1684.

15. Leopold SS, Beadling L, Dobbs MB, Gebhardt MC, Lotke PA, Manner PA, Rimnac CM, Wongworawat MD. Fairness to all: Gender and sex in scientific reporting. Clin Orthop Relat Res. 2014;472:391-392.

16. Leopold SS, Beadling L, Gebhardt MC, Gioe TJ, Potter BK, Rimnac CM, Wongworawat MD. Editorial:
Words hurt-avoiding dehumanizing language in orthopaedic research and practice. Clin Orthop Relat Res. 2014;472:2561-2563.

17. National Archives. 19th Amendment to the US constitution: Women's right to vote. Available at: http://www.archives. gov/historical-docs/document.html?doc $=13 \&$ title.raw $=19$ th + Amendment+to+ the+U.S.+Constitution:+Women's+ Right+to+Vote. Accessed January $18,2015$.

18. National Institute of Health. Best pharmaceuticals for children act. Available at: http://bpca.nichd.nih.gov/about/ Pages/Index.aspx. Accessed January 18, 2015.

19. Newitz A. Think twice before using "mankind" to mean "all humanity," say scholars. Available at: http://io9. com/5962243/think-twice-before-usingmankind-to-mean-all-humanity-sayscholars. Accessed January 6, 2015.

20. NIH Revitalization Act of 1993. Available at: http://orwh.od.nih.gov/ about/pdf/NIH-Revitalization-Act1993.pdf. Accessed January 24, 2015.

21. People. Available at: http://dictionary. reference.com/browse/people. Accessed January 28, 2015.
22. Person. Available at: http://dictionary.reference.com/browse/person. Accessed January 28, 2015.

23. The Library of Congress. A century of lawmaking for a new nation: US congressional documents and debates, 1774 - 1875. Available at: http:// memory.loc.gov/cgi-bin/ampage?colIId $=11$ sl \&fileName $=015 / 11$ s1015.db\& recNum=379. Accessed January 18, 2015.

24. The writer's almanac with Garrison Keillor. Available at: http://writersalmanac.publicradio.org/index.php?date $=2014 / 12 / 06$. Accessed December 6, 2014.

25. United States Department of Labor. Title IX, education amendments of 1972. Available at: http://www. dol.gov/oasam/regs/statutes/titleix.htm. Accessed March 19, 2014.

26. US Constitution Online. Things that are not in the Constitution. Available at: http://www.usconstitution.net/constnot.html\#slavery. Accessed January 15, 2015.

27. World War II posters photo gallery. Available at: http://www.history.com/ photos/world-war-ii-posters/photo13. Accessed January 18, 2015. 